\title{
The effect of season on the ovulatory response of Merino ewes to serum from pregnant mares
}

\author{
P. B. Gherardi and D. R. Lindsay \\ Department of Animal Science and Production, University of Western Australia, Nedlands, \\ Western Australia 6009
}

\begin{abstract}
Summary. Groups of 50 ewes were injected with serum from pregnant mares on 5 occasions, 3 months apart, and ovulation rate was estimated at laparoscopy. In Exp. 1 , new ewes were used at each time and 3 dose rates ( $\equiv 400,630$ and 1000 i.u. PMSG) were studied. In Exp. 2, the same ewes were used throughout and only 1 dose was given (1000 i.u.). In both experiments the response in ovulation rate of ewes varied significantly throughout the year, with the lowest response in spring (September) and the highest in autumn (March). The ewes in Exp. 2 were as responsive at the end as at the beginning of the experiment, indicating that the response was independent of the number of doses given. The results suggest that changes in the sensitivity of ovaries to gonadotrophin may be a factor controlling seasonal ovarian activity in sheep.
\end{abstract}

\section{Introduction}

Ovulation or fertility data for ewes treated with pregnant mares' serum gonadotrophin (PMSG) at specified times of the year are available from many sources (Robinson, 1951, 1962; Gordon, 1958; Hulet \& Foote, 1969; Allison, 1973) but there is little information on seasonal differences in the response. Braden, Lamond \& Radford (1960) suggested that the response to a given dose of PMSG is affected by the time of the year when it is given, because a greater degree of superovulation was obtained in late February than in early January. Lamond (1962) suggested that the possible seasonal effect could be due to a change in sensitivity of the neural-endocrine systems controlling ovarian activity.

If sheep are injected more than once with PMSG, the ovulatory response may decrease (Pigon, Clegg \& Cole, 1960; Hulet \& Foote, 1967; Clarke, 1973). It has been suggested that this is because follicular reserves are depleted (Edwards \& Fowler, 1960) or antibodies or antigonadotrophic factors have been formed (Greenwald, 1963; Land \& McLaren, 1967; Hulet \& Foote, 1969). In none of these studies has it been shown that the decrease in ovarian activity is independent of the possible effects of season on the response of ewes to PMSG.

The present paper examines (1) the effect of season on the ovulatory activity of Merino ewes injected at different times during the year with gonadotrophin and (2) the effect of repeated injections of gonadotrophin on the development of refractoriness of response at the same times of the year. 


\section{Materials and Methods}

\section{Animals}

The sheep were from a flock of about 1000 mature Merino ewes. They were grazed on a subterranean clover-ryegrass pasture and received no supplement at any time.

The serum for use was prepared from the blood of a pregnant mare and assayed by Dr P. Stevenson (Biochemistry Department, University of Western Australia) against a commercial standard of PMSG (Organon, Scotland) in a mouse ovarian weight bioassay. This was a 4 point assay using 7 immature (20-day-old) rats for each point. The rats were killed 7 days after treatment. The correlation between the commercial PMSG and the serum being tested was 0.9657 . Serum from pregnant mares was preferred to commercial preparations because it cost less. The serum was stored at $-15^{\circ} \mathrm{C}$ and appropriate amounts were thawed and injected as required. The oestrous cycles of the ewes were synchronized by giving 6 intramuscular injections of $20 \mathrm{mg}$ progesterone in oil (Syntex Corp., California) on alternate days. On the day of the last progesterone injection, the serum preparation was injected.

\section{Experiments}

Experiment 1. Ewes which had lambed 9 months before the experiment began were allocated at random to 4 groups of 50 for each experimental period. Control ewes received an injection of sterile water, whilst the treated ewes received the equivalent of 400,630 , or 1000 i.u. PMSG in $2.7,4.2$ or $6.7 \mathrm{ml}$ of the serum preparation as single subcutaneous injections. The control group consisted of the same ewes throughout the experiment but new ewes were allocated to treatment groups at each experimental period in March, June, September and December, 1976, and March, 1977.

Experiment 2. Ewes were allocated at random to 2 groups of 50. The same ewes were used throughout the experiment. Control ewes received an injection of sterile water while treated ewes received the equivalent of 1000 i.u. PMSG at each period.

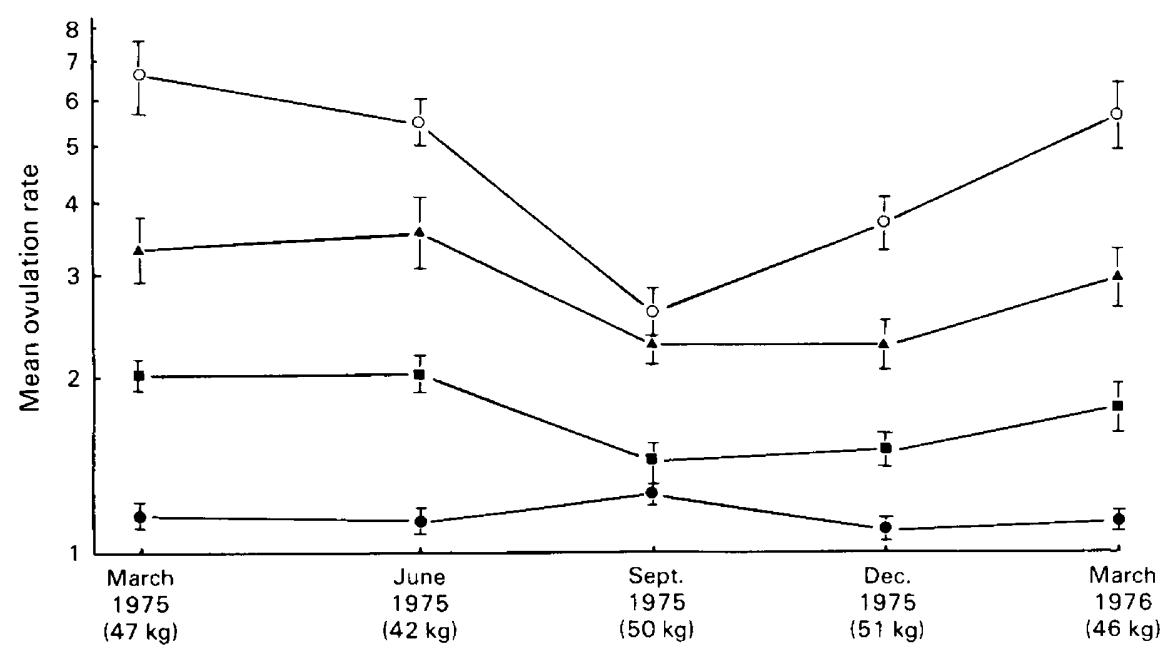

Text-fig. 1. Seasonal variation in the response of ewes to treatment (Exp. 1) with serum from pregnant mares (dose equivalents of 400 i.u. ( $(\mathbf{D}), 630$ i.u. (A) and 1000 i.u. (O) compared with that of controls (O). There were 50 ewes at each point and the s.e.m. of the response is shown. The mean body weight of all the ewes used at each experimental period is shown in parentheses. 
For both experiments, the ewes were weighed each week for 4 weeks before the treatment. They were examined by laparoscopy 5 days after treatment with PMSG and the numbers of fresh corpora lutea were counted. Only 3 ewes failed to ovulate throughout the experiment and ovulation rate for each group was estimated from the mean number of corpora lutea per ewe ovulating.

\section{Analysis of results}

Before analysis, the number of ovulations for individual animals was transformed to natural logarithms. This enabled the transformed variables to approximate more closely to a normal distribution and hence to stabilize the between-group variance.

\section{Results}

\section{Experiment 1}

Body weights. The body weights of the ewes varied throughout the experiment and followed a predictable pattern based on available grazing. Analysis of covariance showed that the changes in body weight before ovulation were not related to the mean ovulation rate at the ovulation.

Ovulation rate. As shown in Text-fig. 1, all doses of serum significantly increased ovulation rates above those of the controls at each time except for September $(P<0.001)$. For all 3 experimental groups the highest mean ovulation rate was in March and the lowest in September. The responses in March 1976 were similar to those in March 1975, indicating that the serum had not changed potency throughout the experiment.

\section{Experiment 2}

Body weight. As in Exp. 1, the body weights of the ewes were not related to the ovulation rate at the same period.

Ovulation rate. The response varied significantly $(P<0.001)$ with season, with a peak in March and trough in September (Text-fig. 2), and ewes receiving successive injections of serum thus showed the same seasonal pattern of response as those in Exp. 1 and there was no evidence of refractoriness.

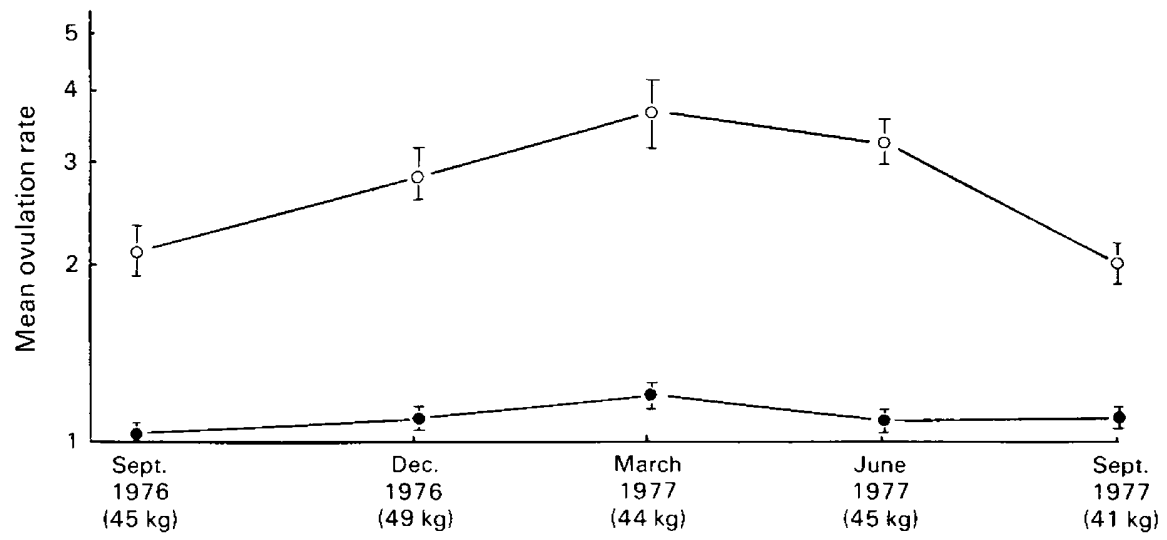

Text-fig. 2. Seasonal variation in the response of ewes to treatment on several occasions (Exp. 2) with serum from pregnant mares at a dose equivalent of 1000 i.u. PMSG $(O)$ compared with that of controls (O). Values are mean \pm s.e.m. for 50 ewes at each point. The mean body weight of all ewes used at each experimental neriod is shown in narentheces 


\section{Discussion}

Both experiments showed that the ovarian response to serum of pregnant mares is strongly influenced by the time of the year in Merino ewes, the response being greatest in March and least in September. The ovulation rate of naturally ovulating animals is also highest about March and lowest in September (Radford, 1959; Dun, Ahmed \& Morrant, 1960). The control ewes in our experiments showed no significant seasonal differences in natural ovulation rate but Gherardi \& Lindsay (1980) have shown that, in similar animals in the same environment, low ovulation in March is because of inadequate nutrition.

There are no published studies which have examined responses of sheep to PMSG throughout the year, but experiments by Braden et al. (1960) and Hulet \& Foote $(1967,1969)$ showed differences in response to PMSG over short intervals which correspond to the seasonal pattern demonstrated here. Saumonde \& Chupin (1977) demonstrated a possible seasonal effect in the response of cattle to injections of PMSG every 7-9 weeks.

Current theory to explain seasonality in ovarian activity in sheep is based on hypothalamic changes in sensitivity to negative feedback by oestradiol on LH secretion (Scaramuzzi \& Baird, 1976; Karsch, Legan, Ryan \& Foster, 1978). Our results show that the ovary itself changed in sensitivity to PMSG through the year, and although this response may be an interaction with endogenous $\mathrm{LH}$ levels, it does suggest that the secretion of LH by the hypothalamus-pituitary system is not the only factor implicated in the control of seasonality in sheep.

We found no evidence in these experiments of refractoriness in animals injected with serum 5 times in 1 year. Gherardi \& Martin (1978) showed that after 17 injections, 17 days apart, ewes did not show evidence of refractoriness or anti-PMSG activity. One explanation for the lack of a detectable immune response could be that the gonadotrophin used in this study and that of Gherardi \& Martin (1978) was crude serum, perhaps providing so many foreign proteins that the recipient's immune system was incapable of developing detectable quantities of antibodies to the active component of PMSG. Had the gonadotrophin been in a purified form, this antigenic competition may have been avoided and an immune response may have resulted.

We therefore suggest that successively smaller responses to PMSG which have been attributed to refractoriness may be due to the effect of season and the time of the year at which the injections were given.

We thank Mr A. Heitman for donating the sheep and Mr J. Knipe on whose property the experiments were conducted; Muresk Agricultural College, Northam, for facilities; and $\mathrm{H}$. Armstrong, D. Suckling and M. Chapman for technical assistance. This project was supported by grants from the Merchants Agricultural Research Trust Fund and the Australian Meat Research Committee.

\section{References}

Allison, A.J. (1973) The effect of liveweight on the ovarian response and fertility of ewes treated with PMSG. Proc. N.Z. Soc. Anim. Prod. 33, 114, Abstr.

Braden, A.W., Lamond, D.R. \& Radford, H.M. (1960) The control of the time of ovulation in sheep. Aust. $J$. agric. Res. 11, 389-401.

Clarke, IJ. (1973) Repeated gonadotrophic stimulation of ewes. Proc. N.Z. Soc. Anim. Prod. 33, 204. Abstr.

Dun, R.B., Ahmed, W. \& Morrant, A. J. (1960) Annual reproductive rhythm in Merino sheep related to the choice of a mating time at Trangie, central western New South Wales. A ust.J. agric. Res. 11, 805-826.
Edwards, R.G. \& Fowler, R.E. (1960) Superovulation treatment of adult mice; their subsequent natural fertility and response to further treatment. J. Endocr. 21, 147-154.

Gherardi, P.B. \& Lindsay, D.R. (1980) Response of ewes to lupin supplementation at different times of the breeding season. Aust. J. exp. Agric. anim. Husb. (in press).

Gherardi, P.B. \& Martin, G.B. (1978) The effect of multiple injections of Pregnant Mares' Serum on the ovarian activity of Merino ewes. Proc. Aust. Soc. anim. Prod. 12, 260, Abstr. 
Gordon, I. (1958) The use of progesterone and serum gonadotrophin (PMS) in the control of fertility in sheep. J. agric. Sci., Camb. 50, 123-197.

Greenwald, G.S. (1963) Effect of anti-PMS serum on superovulation in the hamster. Endocrinology 73, $436-441$.

Hulet, C.V. \& Foote, W.C. (1967) Physiological factors affecting frequency rate of lambing. J. anim. Sci. 26, $553-562$.

Hulet, C.V. \& Foote, W.C. (1969) Ovulatory response of the ewe to repeated injections of PMS. J. Anim. Sci. 29, 457-463.

Karsch, F.J., Legan, S.J., Ryan, K.D. \& Foster, D.L. (1978) The feed-back effects of ovarian steroids on gonadotrophin secretion. In The Control of Ovulation, pp. 29-48. Eds D. B. Crighton, G. R. Foxcroft, N. B. Haynes \& G. E. Lamming. Butterworths, London.

Lamond, D.R. (1962) Effect of season on hormonally induced ovulation in Merino ewes. J. Reprod. Fert. 4, 111-120.

Land, R.B. \& McLaren, A. (1967) The response of female mice to repeated injections of Human
Chorionic Gonadotrophin. J. Reprod. Fert. 13, 321-327.

Pigon, H., Clegg, M.T. \& Cole, H.H. (1960) The formation of antigonadotrophins in sheep and its effect on the endocrine and reproductive system. Acta endocr., Copenh. 35, 253-260.

Radford, H.M. (1959) Variation in the incidence of twin ovulation in Merino ewes on a constant plane of nutrition. A ust. J. agric. Res. 10, 377-386.

Robinson, T.J. (1951) The control of fertility in sheep. II. The augmentation of fertility by gonadotrophin treatment of the ewe in the normal breeding season. J. agric. Sci., Camb. 41, 6-63.

Robinson, T.J. (1962) Comparative studies of several gonadotrophin, progestin and oestrogen treatments in the anoestrous ewe. J. Endocr. 24, 33-35.

Saumonde, J. \& Chupin, D. (1977) Superovulation: a limit to egg transfer in cattle. Theriogenology 7, 141-149.

Scaramuzzi, R.J. \& Baird, D.T. (1976) Ovarian steroid secretion in sheep during anoestrus. In Proc. Int. Sheep Breeding Congr., pp. 330-337. Eds G. T. Tomes, D. E. Robertson \& R. J. Lightfoot. West. Aust. Inst. Tech. Press, Perth. 